УДК 631.563.2: [633.63+631.576.2]:54-162

\title{
ВПЛИВ РЕЖИМУ КОНВЕКТИВНОГО СУШІННЯ НА КРИСТАЛІЧНІСТЬ ПОРОШКІВ 3 ЯБЛУК ТА ЦУКРОВОГО БУРЯКУ
}

\author{
Михайлик В.А. ${ }^{,}$, канд. техн. наук, Снєжкін Ю.Ф. ${ }^{1}$, член-кореспондент НАН України, \\ Корінчевська Т.В. ${ }^{1}$, Горніков Ю.І. ${ }^{2}$ \\ ${ }^{1}$ Інститут технічної теплофізики НАН України, вул. Желябова, 2а, Київ, 03680, Україна \\ ${ }^{2}$ Інститут хімї̈ поверхні ім. О.О. Чуйка НАН Украӥни, вул. Генерала Наумова 17, Київ, 03164, Украӥна
}

\begin{abstract}
Представлено результати дослідження методами дериватографії та рентгенофазового аналізу впливу температури конвективного сушіння на кристалічність порошків з яблук та цукрового буряку. За допомогою термічного аналізу встановлено, що 3 підвищенням температури сушіння 360 до $100{ }^{\circ} \mathrm{C}$, при незмінній швидкості сушильного агента $1,5 \mathrm{~m} / \mathrm{c}$, ступінь кристалічності порошку 3 буряку знижується 3 34,0 до 20,4 \%, а порошку з яблук - 311,1 до 7,7 \%. Рентгенофазовим аналізом ступінь кристалічності бурякових порошків визначена на рівні $36 \%$, яблучних $34 \%$. За ступенем кристалічності досліджені порошки представляють собою аморфно-кристалічні продукти - суміші біополімерів та розчинних вуглеводів в аморфному стані і кристалічних фаз, переважно глюкози, сахарози та фруктози в порошках з яблук, чи сахарози в порошках $з$ цукрового буряку.
\end{abstract}

Представлены результаты иссле- The effect of temperature of the дования методами дериватографии и convecting drying on the crystallinity рентгенофазового анализа влияния of apple and sugar beet powders was температуры конвективной сушки на presented in this study. The X-ray кристалличность порошков из яблок diffraction and derivatography methods и сахарной свеклы. С помощью тер- were used. The data of thermal analysis мического анализа установлено, что revealed that with increasing of drying с повышением температуры сушки с temperature from 60 to $100{ }^{\circ} \mathrm{C}$ at a 60 до $100{ }^{\circ} \mathrm{C}$, при неизменной скоро- constant speed of drying agent $(1.5 \mathrm{~m} / \mathrm{s})$, сти сушильного агента $1,5 \mathrm{~m} / \mathrm{c}$, сте- the degree of crystallinity was reduced пень кристалличности порошка из from $34.0 \%$ wt. to $20.4 \% \mathrm{wt}$. and from свеклы снижается с 34,0 до 20,4\%, $11.1 \%$ wt. to $7.7 \%$ wt. for the sugar а порошка из яблок - с 11,1 до 7,7\%. beet and apple powders, respectively. Рентгено-фазовым анализом степень The X-ray diffraction method showed кристалличности свекольных по- that the crystallinity of sugar beet and рошков определена на уровне $36 \%$, apple powders were $36 \%$ wt. and яблочных - $34 \%$. По степени крис- $34 \%$ wt., respectively. The investigated талличности исследованные порош- powders are semicrystalline product ки представляют собой аморфно- according to their degree of crystallinity. кристаллические продукты - смеси Е.g., the apple powder is a mixture of биополимеров и растворимых угле- amorphous (biopolymers and soluble водов в аморфном состоянии и крис- carbohydrates) and crystalline (glucose, таллических фаз, преимущественно sucrose and fructose) phases.

глюкозы, сахарозы и фруктозы в яблочных порошках или сахарозы в порошках из сахарной свеклы.

Бібл. 34, табл. 3, рис. 8 .

Ключові слова: сушіння, цукровий буряк, яблука, кристалізація, сахароза, глюкоза, фруктоза, дериватографія, рентгенофазовий аналіз, фазові переходи, ступінь кристалічності.

$d$ - міжплощинна відстань, нм;

$F$ - площа піка плавлення, мВ·с;

$h_{1 / 2}$ - півширина піка, град;

$I$ - інтенсивність відбиття, $\mathrm{c}^{-1}$;

$K-$ коефіцієнт пересичення розчину (соку) сахарозою;

$m$ - маса, кг;

$N$ - ступінь кристалічності, \%;

$Q$ - інтегральна теплота плавлення, кДж; $q$ - коефіцієнт перерахунку площі піка плавлення в теплоту, кДж (мВ·с) $)^{-1}$;

$t$ - температура, ${ }^{\circ} \mathrm{C}$;

$\mathrm{Tg}$ - температура склопереходу;

$W$ - вологовміст, \%;

$\Delta H$ - питома теплота плавлення, кДж·кг $\Gamma^{-1}$;

$\theta$ - кут падіння-відбиття пучка рентгенівського випромінювання, град. 


\section{Верхній індекс:}

$$
\begin{aligned}
& 60-60{ }^{\circ} \mathrm{C} ; \\
& 80-80{ }^{\circ} \mathrm{C}: \\
& 100-100{ }^{\circ} \mathrm{C} .
\end{aligned}
$$

\section{Нижній індекс:}

cr - кристалічна фаза;

$f$ - кінець плавлення;

$g l$ - глюкоза;

$d e g-$ початок термічного розкладання (деградація);

d.s - сухі речовини;

$d t a$ - диференціальний термічний аналіз;

\section{Bcmyn}

В останній час все більше висушених овочів $\mathrm{i}$ фруктів одержують в порошкоподібному вигляді, через зручність їх використання в хлібопекарному та кондитерському виробництві, в виробництві продуктів швидкого приготування та ін. Основні параметри сушіння залежать від хімічного складу сировини. Наявність в ній біологічно активних речовин та розчинних вуглеводів потребують корегування процесу сушіння з врахуванням особливостей їх біо- та фізико-хімічних властивостей. При розгляді процесів, що відбуваються при сушінні фруктів і овочів, головну увагу приділяють фазовим переходам і механізмам переносу води, збереженню харчових властивостей продукту та енергетичній ефективності сушіння. Нажаль, мало приділяється уваги фазовим перетворенням, що відбуваються за участю основних розчинених компонентів соку: глюкози, фруктози та сахарози. Завдяки високій гідратаційній спроможності ці вуглеводи в основному зумовлюють вологоутримуючі та кріопротекторні властивості рослинних тканин [1 - 5]. Сировина 3 високим вмістом моно- та дисахаридів особливо важко зневоднюється на завершальному етапі сушіння [6], що призводить до зниження загальної енергетичної ефективності процесу. Причиною $\epsilon$ те, що зневоднюванню в основному підлягає сік, кількість якого в овочах і фруктах в середньому становить 91...92\% до маси сировини. В процесі сушіння концентрація соку неухильно зростає, досягаючи при певному вологовмісту критичного пересичення, що спонукає до криста- $i$ - початок плавлення;

ref- еталонна речовина;

$x r d$-рентгенофазовий аналіз;

$s$ - концентрація насичення;

sug - caxароза;

int - інтегральна інтенсивність відбиття;

\section{Скорочення:}

ДТА - диференціальний термічний аналіз;

ДТГ - диференціальна термогравіметрія;

РФА - рентгенофазовий аналіз;

$\mathrm{T}$ - температура;

ТГ - термогравіметрія.

лоутворення. Через високу в’язкість концентрованих соків видалення води 3 внутрішніх шарів рослинних тканин ускладнене. Випаровування здійснюється з зовнішнього шару, що призводить до локального зростання коефіцієнта пересичення i, як результат, до утворення кристалічного шару (кірки), який може замикати розчин. Видалення води 3 замкнутих об'ємів відбувається або в результаті мікровибухів, при різкому зростанні тиску всередині об'єму, або дифузійним шляхом, що значно подовжує час сушіння.

Швидкість утворення кристалічної фази вуглеводів і iї масове зростання в нечистих розчинах, якими є соки, залежить від виду цукру, температури, коефіцієнту пересичення розчину, концентрації нецукрів та швидкості зневоднення [7]. Якщо швидкість зневоднення перевищує швидкість кристалізації, зростає коефіцієнт пересичення розчину і разом 3 прискоренням росту основної маси кристалів утворюються нові центри кристалізації [8].

Фазовий склад висушених продуктів, дисперсність гідрофільних компонентів та вологість визначають гігроскопічність, умови диспергування, сепарації та зберігання. За наявністю аморфних компонентів та зв'язаної води, яка виконує роль пластифікатора, в тканинах ягід [9 - 11], фруктів [12 - 15] та овочів [16] 3 низькою вологістю спостерігаються процеси склування/розсклування (фазові переходи другого роду) при подоланні температури склопереходу $\mathrm{Tg}$. Підвищення температури матеріалу 3 такою вологістю вище $T g$ призводить до розсклування: 
тверде тіло переходить в еластичний стан, який унеможливлює ефективне його диспергування та сепарацію. Охолодження нижче $T g$ викликає зворотній процес - склування, в результаті якого матеріал знову набуває властивостей твердого тіла. Дослідники продовжують обговорювати використання факту склування в прогнозуванні мікробіологічних, фізичних та хімічних змін в продукті, що відбуваються в процесі обробки та зберігання. Продукт може бути стабільним при зберіганні нижче температури склопереходу у зв'язку з значним зниженням активності води, від величини якої залежать мікробіологічні та хімічні процеси [14].

В зв'язку з цим дослідження формування фазового стану основних компонентів рослинної сировини з різним складом та вмістом розчинних вуглеводів при сушінні має не тільки науковий, а і вагомий практичний інтерес.

\section{Матеріали та методи}

Матеріали. В дослідженні були використані яблука та цукровий буряк. Яблука сорту «Делікатес» були зірвані в кінці вересня 2014 року в саду ІТТФ НАН України, м. Київ. Цукрові буряки вирощені в с. Гребінка Київської обл. та викопані в жовтні 2014 року.

В ході підготовки до сушіння 3 яблук та кореню цукрового буряку був видалений зовнішній шар. Паренхімні тканини яблука та буряку нарізали смужками довжиною 40...50 мм і поперечним розрізом $3 \times 3$ мм.

Для порівняння температур та теплоти фазових перетворень в порошках з яблук була використана глюкоза харчова (ГОСТ 975-88).

Методи. Сушіння здійснювали на експериментальному конвективному стенді [17] за температури сушильного агента (повітря) 60, 80 та $100{ }^{\circ} \mathrm{C}$ і швидкості - 1,5 м/с. Смужки досліджуваних матеріалів розташовували одним шаром вподовж напрямку руху повітря на відстані 3 мм одна від одної на ситову підкладку, яку встановлювали на тримач електронних ваг в камері вимірювання [18]. Маса зразків знаходилась в межах 20...26 г.

Термічні дослідження проводили в дериватографі «Q-1000» системи Paulik-PaulikErdey (фірма «МОМ», Угорщина) [19] в діапазоні $20 . .250{ }^{\circ} \mathrm{C}$ при швидкості нагрівання $3,6 \mathrm{~K} / \mathrm{xв}$.
Зразки розміщували в відкритий конічний платиновий тигель. В якості інертної речовини в тиглі порівняння використовували оксид алюмінію. Корекцію шкали температур здійснювали по температурі плавлення бензойної кислоти $\left(122,4{ }^{\circ} \mathrm{C}\right)$ [20]. Відхилення температури не перевищувало $\pm 0,5$ К. Збір та обробка інформації з дериватографа здійснювались за допомогою прикладної комп'ютерної програми «Derivatograph», створеної в середовищі програмування Delphi [21].

Рентгенофазовий аналіз (РФА) порошків 3 яблука та цукрового буряку виконували на дифрактометрі ДРОН-4-07 в відфільтрованому нікелем $\mathrm{Cu} \mathrm{K}$ випромінюванні аноду та геометрії зйомки по Бреггу-Брентано [22].

\section{Результати досліджень та аналіз одержсаних даних}

Необхідно відмітити, що матеріал для дослідження був вибраний свідомо. За хімічним складом яблука суттєво відрізняються від кореня цукрового буряку (таблиця 1) [23, 24]. Основною відмінністю $є$ вміст сухих речовин та склад розчинних вуглеводів. Загальний вміст розчинних вуглеводів залежить від сорту, умов і місця вирощування, періоду збирання та зберігання. В яблуці основну частину розчинних вуглеводів складають моносахариди - фруктоза $(\sim 6,0 \%)$ i глюкоза $(\sim 2,4 \%)$, вміст дисахариду сахарози становить лише $\sim 2,0 \%$. В зрілому корені цукрового буряку, навпаки, сахароза є основним компонентом сухих речовин, іiі вміст складає біля $70 \%$, а глюкоза та фруктоза відсутні. Вміст соку в цукровому буряку і яблуках становить 91...92\%.

Процес сушіння зразків відображений кривими сушіння та швидкості сушіння на рис. 1. Для можливості порівняння швидкостей сушіння вологовміст в координатах «швидкість - вологовміст» представлено безрозмірною величиною. Видно, що при рівних умовах сушіння, через значну різницю в вихідних значеннях вологовмісту, швидкість зневоднення яблучних тканин вища за швидкість зневоднення тканин цукрового буряку.

Під час нарізання сировини перед сушінням частина клітин механічно пошкоджується, причому в результаті поширення механічної деформації ушкодження зазнають клітини не тільки поверхневого шару, що полегшує їх 
зневоднення [25]. Цей факт, а також прогрів матеріалу, відображаються на кривих швидкості сушіння в вигляді різкого її зростання, яка, досягнувши максимуму, спадає практично лінійно. В неушкоджених клітинах елементарні об'єми соку залишаються ізольованими один від одного поки захисні властивості оболонки (протоплазми) клітин не будуть втрачені в результаті дії темпе- ратури та зневоднення. Температура денатурації протоплазми залежить від видової належності сировини і здебільше поріг денатурації білка протоплазми рослинних клітин знаходиться в районі $60{ }^{\circ} \mathrm{C}$. Так протоплазма кореня цукрового буряку денатурує в інтервалі $60 . .70^{\circ} \mathrm{C}$ [24].

Таблиця 1. Усереднений вміст (г) основних компонентів в яблуках та коренях цукрового буряку, в 100 г продукту

\begin{tabular}{|c|c|c|c|c|c|c|c|c|c|c|}
\hline Вода & $\begin{array}{c}\text { Моноса- } \\
\text { хариди }\end{array}$ & $\begin{array}{c}\text { Диса- } \\
\text { хариди }\end{array}$ & $\begin{array}{c}\text { Геміцелю- } \\
\text { лоза }\end{array}$ & $\begin{array}{c}\text { Клітко- } \\
\text { вина }\end{array}$ & $\begin{array}{c}\text { Пектинові } \\
\text { речовини }\end{array}$ & Білки & Жири & $\begin{array}{c}\text { Органічні } \\
\text { кислоти }\end{array}$ & Зола \\
\hline \multicolumn{10}{|c|}{ Яблука } \\
\hline 84,4 & 8,4 & 2,0 & - & 2,1 & 1,0 & 0,4 & 0,4 & 0,8 & 0,5 \\
\hline \multicolumn{8}{|c|}{ Цукровий буряк } \\
\hline 75,0 & 0,1 & 17,5 & 1,1 & 1,2 & 2,5 & 0,7 & 0,03 & 0,47 & 0,6 \\
\hline
\end{tabular}

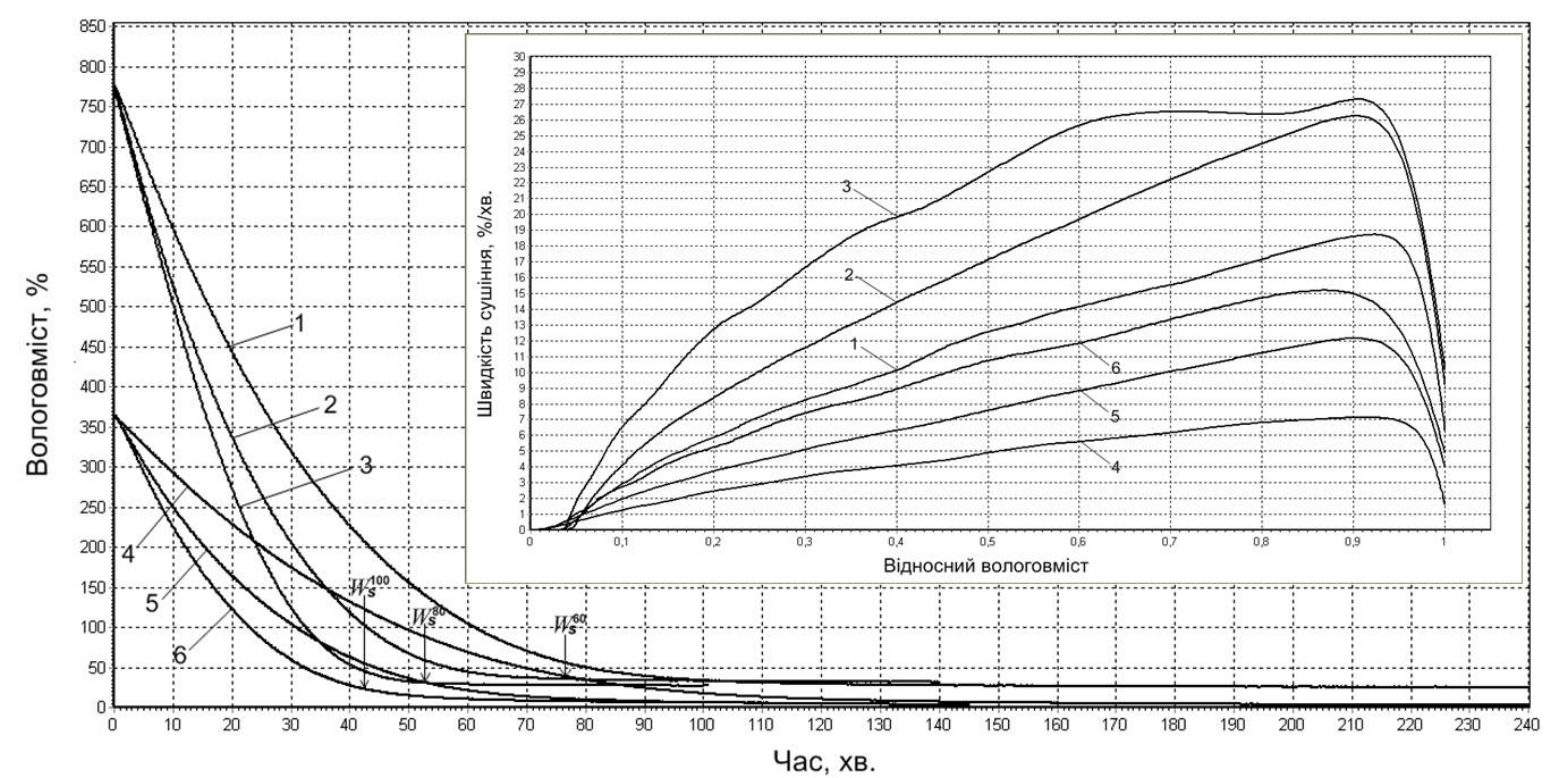

Рис. 1. Кінетика та швидкість сушіння паренхімних тканин яблука $(1,2,3)$ та цукрового буряку $(4,5,6)$ при температурі: $60(1,4), 80(2,5)$ ma $100{ }^{\circ} \mathrm{C}(3,6)$. Швидкість суиильного агента $1,5 \mathrm{~m} / \mathrm{c}$.

При конвективному сушінні температура матеріалу залишається нижчою температури сушильного агенту і досягає його температури лише в кінці процесу зневоднення. Тобто при сушінні до денатурації протоплазми сік і його компоненти залишаються зосередженими в клітинах. Кристалізація компонентів соку, відносно яких розчин набуває насичення, розпочинається на зовнішній поверхні тканин в розірваних клітинах, 3 яких видалення води проходить в першу чергу і $з$ найвищою швидкістю (рис. 1). В пересичений розчин цих клітин центри кристалізації можуть бути внесені з повітря [7].

Не вдаючись у тонкощі механізму перенесення вологи в рослинних тканинах при сушінні можна припустити, що у міру зневод- 
нення матеріалу і зростання коефіцієнту пересичення кристалізація 3 периферійної частини переміщується в глиб тканини.

Використовуючи залежності розчинності сахарози від температури [26] та гідратації тканин цукрового буряку від вологості [4], були розраховані значення вологовмісту тканин $W_{s}$, при якому концентрація сахарози в соку досягає насичення за 60,80 та $100{ }^{\circ} \mathrm{C}: W_{s}^{60}=38,60 \%$, $W_{s}^{80}=30,65 \%$ та $W_{s}^{100}=22,78 \%$. Отримані величини $W_{s}$ дають можливість за кінетичними кривими сушіння (рис. 1) визначити час $\tau$, після досягнення якого розчин стає пересиченим відносно сахарози. В умовах сталої швидкості сушильного агента $\tau$ залежить від температури сушіння: $\tau^{60}=76,4$ хв.; $\tau^{80}=52,8$ хв.; $\tau^{100}=42,6$ хв.

Подальше зневоднення призводить до ще більшого концентрування соку, ступінь якого може бути оцінена видимим коефіцієнтом пересичення $K$, що представляє собою відношення вмісту сахарози (г / г води) в соку до вмісту са- харози за тієї ж температури в чистому насиченому розчині [26] (рис. 2).

Таке зростання коефіцієнту пересичення можливе лише в випадку, коли процес кристалізації не запущений. Відомо, що початок гомогенної кристалізації неможливо передбачити i, що спонтанна кристалізація сахарози у відсутності центрів кристалізації може розпочинатись при дуже високому пересиченні розчину [7]. В цукровій промисловості рекомендованою величиною для утфелю другої кристалізації з чистотою $82 \ldots 87 \% € K=1,30 \ldots 1,35$, що дає можливість підтримувати максимальну швидкість кристалізації, не допускаючи вторинного кристалоутворення [7]. Кристалізація сахарози в тканинах буряку з чистотою соку $88 . .89$ \% скоріш за все буде відбуватись при $K>1,35$. Враховуючи температурну залежність розчинності сахарози, межа метастабільної зони буде подолана при вологовмісту тканин $W \leq 28,54,22,62$ та $16,76 \%$ за температури 60,80 та $100{ }^{\circ} \mathrm{C}$, відповідно.

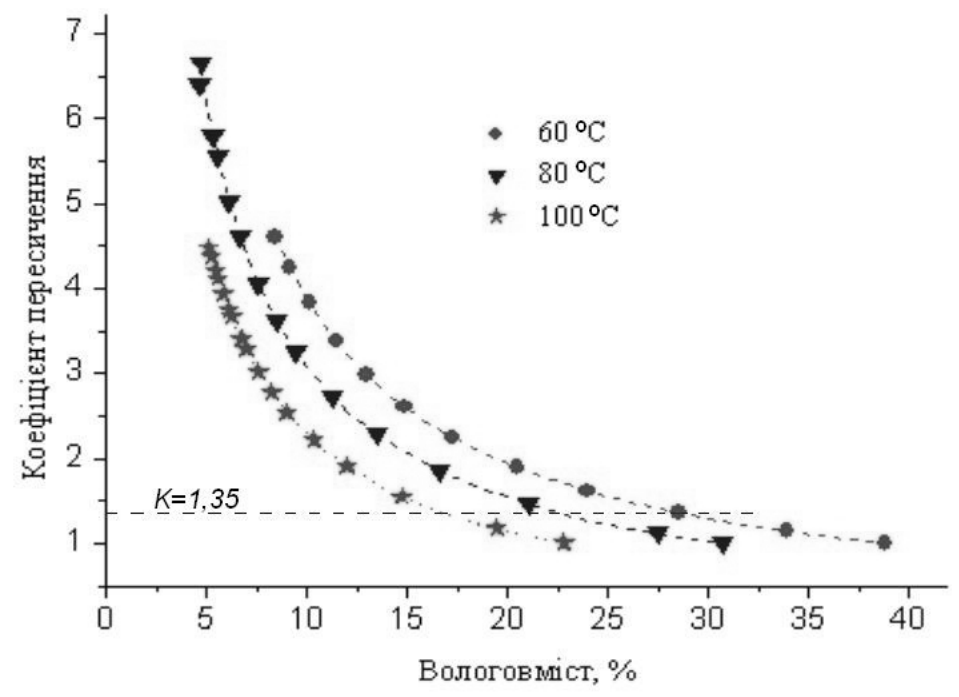

Рис. 2. Очікувана зміна коефіцієнту пересичення соку під час сушіння тканин цукрового буряку за умови відсутності кристалізації сахарози.

Швидкість кристалізації з підвищенням температури сушіння зростає через більш стрімке наростання коефіцієнту пересичення, зменшення в'язкості соку та позитивний вплив температури на дифузійну та кристалохімічну стадії процесів росту кристалів [7].

При безперервному i інтенсивному зневодненні міжкристального розчину концентрація його стрімко наростає, збільшується в'язкість, ускладнюється процес дифузії сахарози до зростаючих кристалів, чистота міжкристального розчину погіршується, в результаті чого швидкість кристалізації падає. Настає період, коли швидкість зневоднення значно перевищує швидкість кристалізації, сахароза не встигає викристалізуватись і утворює аморфну масу.

Дослідження порошків цукрового буряку ме- 
тодом дериватографії показало, що плавлення сахарози відбувається в інтервалі $170 \ldots 195{ }^{\circ} \mathrm{C}$ (рис. 3, крива ДТА, рис. 6, криві 4, 5 та 6). Температури максимумів піків плавлення знаходяться в діапазоні температур плавлення сахарози, отриманих в роботі [27]. Площа (затемнена) $F_{s u g}$, що обмежена піком плавлення та лінією, яка з'єднує точки початку плавлення $t$. i його завершення $t_{f}$ пропорційна інтегральній теплоті плавлення сахарози $Q_{s u g}$. Температуру $t_{f}$ визначали в точці злому висхідної кривої ДТА піка плавлення, яка розділяє процеси плавлення та термічної деструкції порошку. Порівнюючи $t_{f}$ з температурою початку термічного розкладання порошку $t_{d e g}$ (рис. 3, крива ДТГ) бачимо, що термічна деградація порошку починається ще до закінчення плавлення сахарози. Накладання цих двох процесів призводить до незначного зменшення величини $Q_{\text {sug }}$.

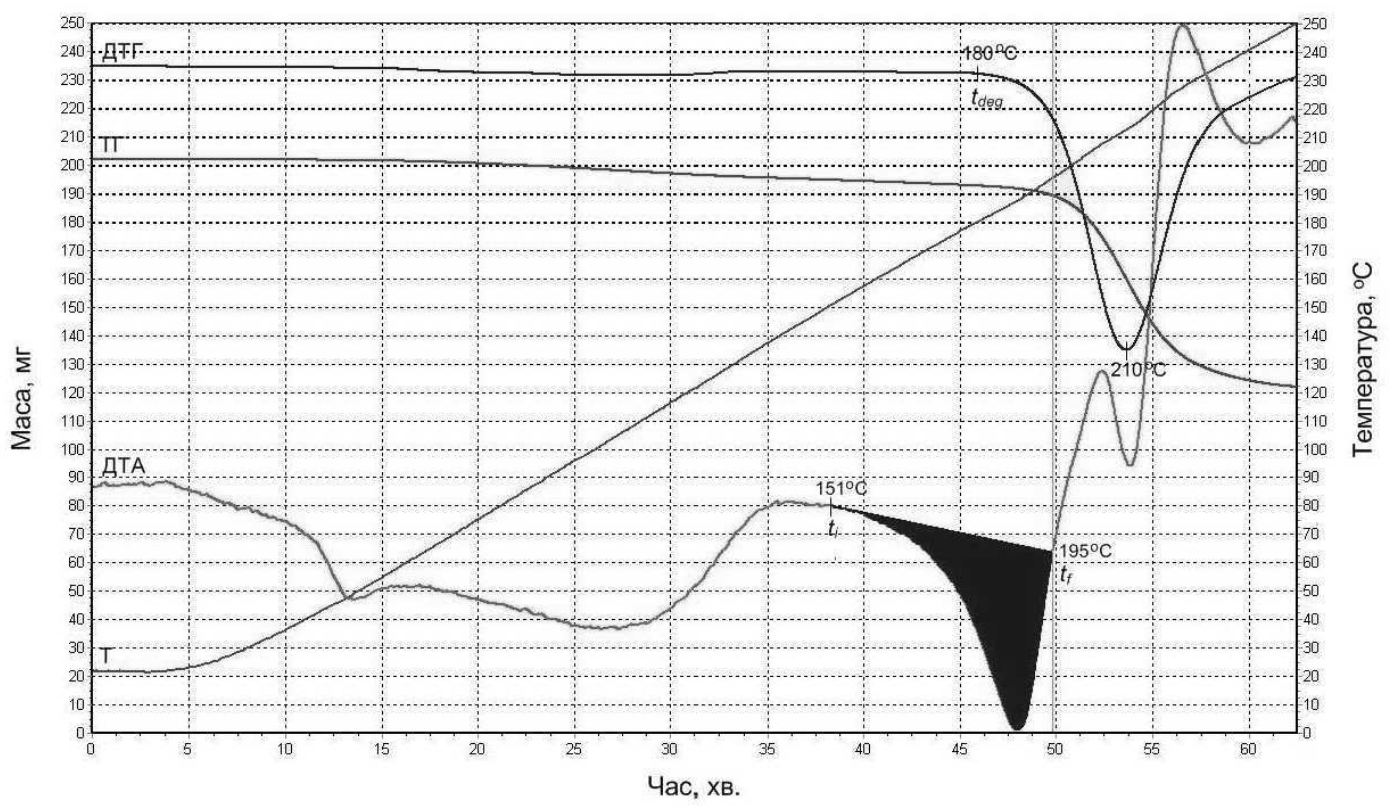

Рис. 3. Дериватограма порошку, отриманого з кореня цукрового буряку після сушіння при $60^{\circ}$ С. Маса зразка 202,0 м2.

Температура сушіння не впливає на $t_{f}$
कарози, тоді як $t$ зростає 3 підвищенням сахарози, тоді як $t_{i}$ зростає 3 підвищенням
температури: $t^{60}=151{ }^{\circ} \mathrm{C} ; t^{80}=160{ }^{\circ} \mathrm{C} ; t^{100}=$ $=170{ }^{\circ} \mathrm{C}$ (рис. 3). Таке переміщення $t_{i}$ може бути наслідком відмінності чистоти та дисперсного складу кристалів сахарози, утвореними в різних умовах зростання пересичення розчину [7, 28].

Інтегральну теплоту плавлення сахарози визначали за результатами градуювання ДТА дериватографа за допомогою стеаринової кислоти $\left(\Delta H_{r e f}=198,9\right.$ Дж $\left.\Gamma^{-1}\right)-$ еталонної речовини, що використовується при калібруванні приладів ДТА та ДСК [29]:

$Q_{\text {sug }}=\left(m_{\text {ref }} \Delta H_{r e f} F_{\text {sug }}\right) / F_{r e f}$.

Масу кристалічної сахарози в порошках розраховували, приймаючи питому теплоту плавлення сахарози $\Delta H_{\text {sug }}=111,4$ Дж $\Gamma^{-1}[27]$ : $m_{\text {sug }}=Q_{\text {sug }} / \Delta H_{\text {sug }}$.

Звісно, дериватографія не може конкурувати 3 калориметрією і досягнути високої точності в визначенні теплоти ендо- чи екзотермічних реакцій в дериватографі «Q-1000» неможливо, проте в даному випадку, при дотриманні незмінних умов проведення дослідів можливо отримати оцінювальні результати на досить хорошому рівні. Так, відхилення у визначенні коефіцієнту перерахунку площі піка плавлення в теплоту плавлення $q=\left(m_{r e f} \Delta H_{r e f}\right) / F_{r e f}$ за результатами плавлення стеаринової кислоти $\left(q=0,02546\right.$ Дж $\left.\mathrm{mB}^{-1} \mathrm{c}^{-1}\right)$ та ангідридної частини харчової глюкози $\left(q=0,02647\right.$ Дж $\left.\mathrm{mB}^{-1} \mathrm{c}^{-1}\right)$ не перевищувало 3,81 \%. Похибка в визначенні $q$ по результатам градуювання стеариновою кислотою склала $0,51 \%$. 
Порівнюючи кількість кристалічної сахарози в сухих речовинах (ступінь кристалічності) порошків з буряку, бачимо, що її вміст залежить від температури сушіння (рис. 4). Чим вища температура сушіння, тим менше сахарози переходить в кристалічний стан. За температури сушильного агента $60{ }^{\circ} \mathrm{C}$ кристалічну фазу утворює тільки половина сахарози, що знаходиться в соку. В результаті підвищення температури до $100{ }^{\circ} \mathrm{C}$ вміст кристалів сахарози зменшується до 20,3%. Видно, що використані режими сушіння не збалансовані щодо швидкості зневоднення з кінетикою кристалізації сахарози. Масова кристалізація сахарози не поспіває за темпом зневоднення i значна iï частина утворює тверду аморфну фазу. Таку сахарозу можна розглядати як переохолоджену рідину в скловидному стані [30].

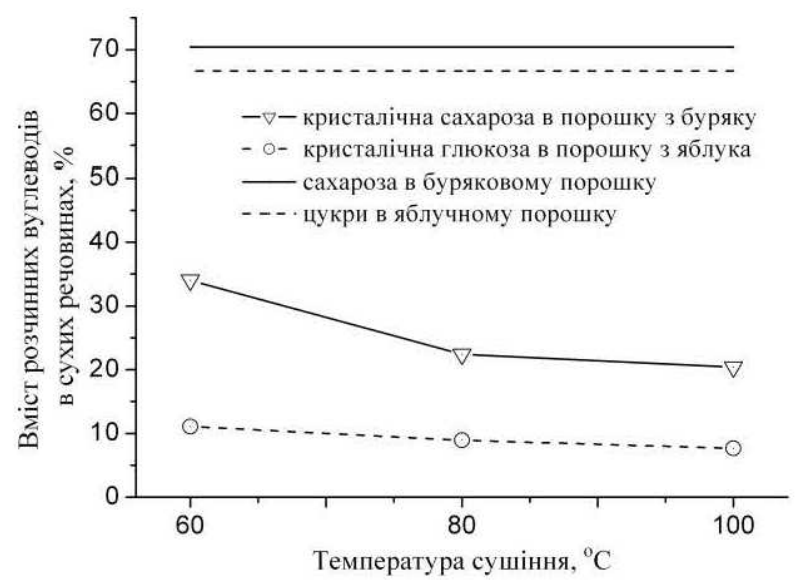

Рис. 4. Залежність вмісту кристалічних сахарози в порошках з цукрового буряку $і$ глюкози в порошках з яблук від температури сушіння та загальний вміст цукрів в порошках.

На відміну від цукрового буряку в соку яблука знаходяться фруктоза, глюкоза та сахароза. Найвищу розчинність має фруктоза. В 100 г води при $55{ }^{\circ} \mathrm{C}$ розчиняється 740,32 г фруктози, 261,7 г глюкози та 273,0 г сахарози [26]. В літературі відсутні дані про взаємний вплив на розчинність цукрів в чотирьох компонентній системі вода-сахароза-глюкоза-фруктоза. Проте є відомості [31] про розчинність в системі вода-фруктоза-глюкоза, де показано, що 3 підвищенням температури розчинність глюкози в присутності фруктози і розчинність фруктози в присутності глюкози зростає. Визначити за кінетичними кривими сушіння значення вологовмісту тканин, при яких досягається насичення соку відносно трьох розчинених в ньому вуглеводів, практично неможливо. Отже, в процесі сушіння паренхімних тканин яблук в кристалічний стан 3 різною чистотою можуть переходити всі розчинені в соку цукри. Виходячи з їх розчинності, можна передбачити, що при зневодненні паренхімних тканин яблук спочатку утворюються кристалічні фази глюкози та сахарози і тільки під кінець сушіння кристалізується фруктоза. Стійкою кристалічною формою глюкози вище $50{ }^{\circ} \mathrm{C} є$ безводна $\alpha-\mathrm{D}-$ глюкоза, фруктоза кристалізується в вигляді $\beta$-d-фруктопіранози [26].

Дериватографічні дослідження яблучних порошків (рис. 5, криві ДТГ та ДТА, рис. 6, криві 1, 2 та 3) показали, що при нагріванні зразків в інтервалі $20 \ldots 179,1{ }^{\circ} \mathrm{C}$ спостерігається декілька ендотермічних процесів. До $121 \ldots 124{ }^{\circ} \mathrm{C}$ одночасно протікають дегідратація порошку та плавлення $\beta$-d-фруктози $\left(102 \ldots 104{ }^{\circ} \mathrm{C}\right.$ [20]), а в інтервалі $134,1 \ldots 179,1{ }^{\circ} \mathrm{C}$ - плавлення глюкози. Температура сушіння не вплинула на $t_{i}$ глюкози, тоді як $t_{f}$ зменшується зі збільшенням температури сушіння: $t_{f}^{60}=179,1 ; \quad t_{f}^{80}=177,1 ; t_{f}^{100}=171,6^{\circ} \mathrm{C}$. Після завершення плавлення глюкози реєструються екзотермічні процеси прискореної термічної деструкції термолабільних компонентів порошку (рис. 5, криві ДТА та ДТГ), теплота яких компенсує теплопоглинання при плавленні сахарози, що відображається на кривій ДТА в інтервалі $179,1 \ldots 200{ }^{\circ} \mathrm{C}$. В зв’язку 


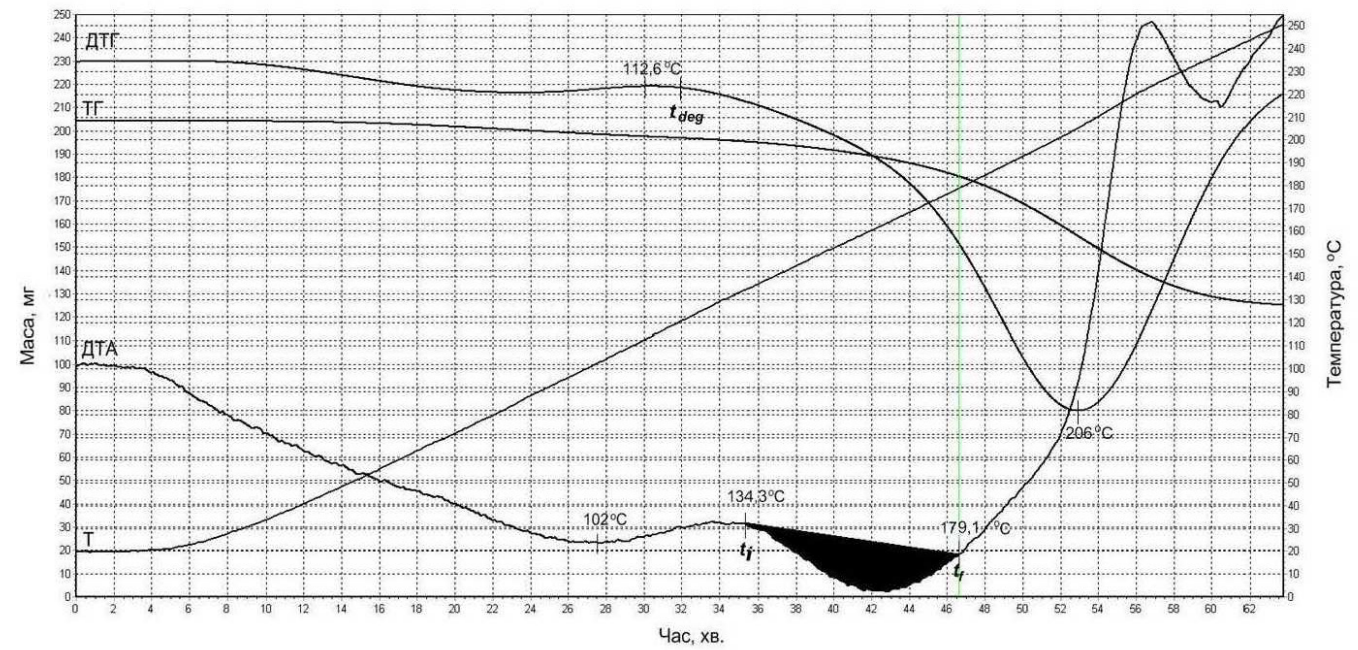

\section{Рис. 5. Дериватограма порошку, отриманого з паренхімних тканин яблука після сушіння при $60^{\circ} \mathrm{C}$. Маса зразка 204,0 мг.}

3 сумісним протіканням процесів визначити теплоту плавлення фруктози та сахарози не представляється можливим.

Максимуми температури піків плавлення глюкози в порошках співпадають 3 максимумом піка плавлення безводної частини гідратної $\alpha$-D-глюкози (рис. 6, крива 7) та максимумами піків плавлення, отриманих методом ДСК [27] для безводної $\mathrm{D}(+)$-глюкози фірми «Fluka BioChemica» 151,9 та $159,4^{\circ} \mathrm{C}$ і фірми «BDH, AnalR» - 154,8 та $163,1{ }^{\circ} \mathrm{C}$, при швидкостях сканування 2 та 10 K/хв., відповідно. Проведена ідентифікація дозволяє стверджувати, що зареєстровані піки плавлення в порошках яблук відповідають кристалічній фазі $\alpha$-D-глюкози. Вміст кристалічної глюкози визначали аналогічно визначенню кристалічної сахарози в порошках $з$ буряку. Масу кристалів розраховували за формулою (2), використовуючи значення питомої теплоти плавлення ангідридної $\alpha$-D-глюкози $\left(\Delta H_{g l}=187,1\right.$ Дж $\left.\Gamma^{-1}\right)$ [27]. Результати вимірювань, розрахунків та визначення ступеня кристалічності порошків наведені в таблиці 2.

3 отриманих даних видно, що близько $72 \%$ глюкози яблук переходить в кристалічний стан при температурі сушіння $60{ }^{\circ} \mathrm{C}$. Підвищення температури сушильного агента до $100{ }^{\circ} \mathrm{C}$ призводить до збільшення швидкості зневоднення (рис. 1, криві 1, 2 та 3), скорочення часу пе- ребування розчину в метастабільному стані, стрімкого зростання коефіцієнту пересичення та, як і при сушінні тканин цукрового буряку, до зменшення ступеня кристалічності порошку $N_{d t a}$. Необхідно мати на увазі, що $N_{d t a}$ розраховано тільки по вмісту глюкози в кристалічному стані. Тобто величина $N_{d t a}$, отримана дериватографічним методом, явно занижена - в ній відсутні вклади кристалічних фаз фруктози та сахарози, визначити які по теплоті плавлення не вдалося.

Як видно 3 дериваторам (рис. 3 та 5) досліджені порошки суттєво відрізняються за термічною стійкістю. В порошках 3 цукрового буряку $t_{d e g}=180^{\circ} \mathrm{C}$, максимальної швидкості термічне розкладання набуває при $210{ }^{\circ} \mathrm{C}$. В яблучних порошках через присутність фруктози деструкція починається $3120 \ldots 122{ }^{\circ} \mathrm{C}$, досягаючи максимальної швидкості при 205...207 ${ }^{\circ} \mathrm{C}$. Цей факт дає підставу вважати, що отримані методом дериватографії величини $N_{d t a}$ яблучних порошків дещо занижені.

Одночасно 3 дериватографічними дослідженнями ступінь кристалічності порошків визначали методом РФА. Дифрактограми порошків 3 яблук та буряку, отриманих 3 паренхімних тканин за різних температур сушіння, представлені на рис. 7 та 8. На дифрактограмах спостерігаються три розширених максимуми, які частково перекриваються. 
Таблиця 2. Результати вимірювань та розрахунків ступеня кристалічності порошків по даним ДТА

\begin{tabular}{|l|c|c|c|c|c|c|c|}
\hline \multicolumn{1}{|c|}{ Показник } & \multicolumn{5}{c|}{ Температура сушіння, ${ }^{\circ} \mathrm{C}$} \\
\hline & 60 & 80 & 100 & 60 & 80 & 100 \\
\hline & \multicolumn{2}{|c|}{ Порошок з цукрового } & \multicolumn{5}{c|}{ Порошок з яблук } \\
\hline Маса зразка, мГ & \multicolumn{2}{|c|}{ буряку } & \multicolumn{3}{c|}{203,4} & 199,2 \\
\hline Маса сухих речовин, $m_{d s}$, Мг & 201,8 & 204,0 & 204,0 & 203,4 & 193,5 \\
\hline Вологість, \% мас. & 194,5 & 195,9 & 196,7 & 196,7 & 197,6 & 193 \\
\hline Інтегральна теплота плавлення, $Q$, Дж & 3,72 & 2,92 & 3,58 & 3,58 & 2,85 & 2,86 \\
\hline Маса кристалічної фази, $m_{c r}$, мг & 7,37 & 4,89 & 4,45 & 4,09 & 3,30 & 2,78 \\
\hline Ступінь кристалічності, $N_{d t a}=m_{c r} / m_{d . s} \%$ & 34,0 & 22,4 & 20,3 & 11,1 & 8,9 & 7,7 \\
\hline
\end{tabular}

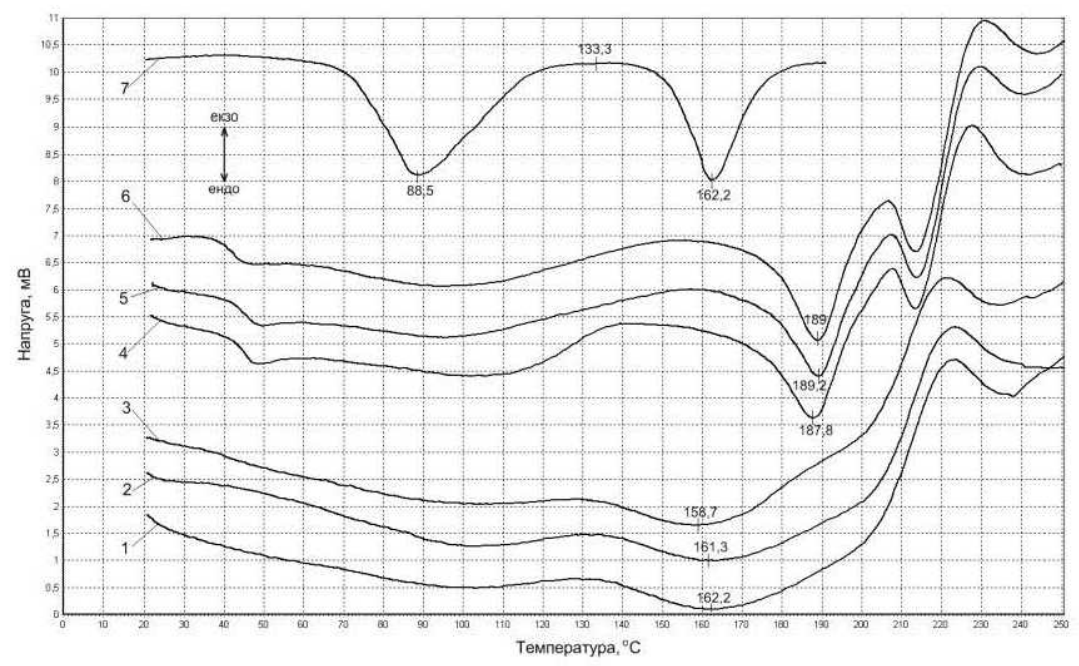

Рис. 6. Криві ДТА порочків з паренхімних тканин яблук $(1,2,3)$, кореня цукрового буряку $(4,5,6)$, одержсаних після сушіння при $60(1,4), 80(2,5)$ і $100^{\circ}$ С $(3,6)$ та гідратної глюкози (4).

В таблиці 2 наведені характеристики дифракційних піків, що отримані в результаті математичного розкладання піків 3 використанням апроксимуючої форми піка функції Гауса.

Значення міжплощинних відстаней $d$ характеризують середні величини відстаней між ланцюгами або їх частинами органічних молекул досліджуваних продуктів. Півширину піків $h_{1 / 2}$ можна співвіднести зі ступенем кристалічності областей 3 таким упорядкуванням. Співвідношення інтегральних інтенсивностей піків $I_{i n t}$ корелює 3 співвідношенням об'ємів речовини з періодичністю, яка характеризується відповідною міжплощинною відстанню [22].

Аналіз отриманих даних показує, що зміна температури сушіння від 60 до $100{ }^{\circ} \mathrm{C}$ не призводить до суттєвих змін структури висушених продуктів, тому на рисунках 7 (б) та 8 (б) представлено розкладання дифрактограм порошків 3 тканин, висушених тільки при $60^{\circ} \mathrm{C}$.

Результати рентгенофазового аналізу свідчать про неоднорідність структури порошків і наявність областей 3 різним ступенем кристалічності 3 характерними для них параметрами періодичності (міжплощинними відстанями). До більш кристалічних областей можна віднести ті, в яких параметри періодичності складають 0,5...0,4 нм для порошків 

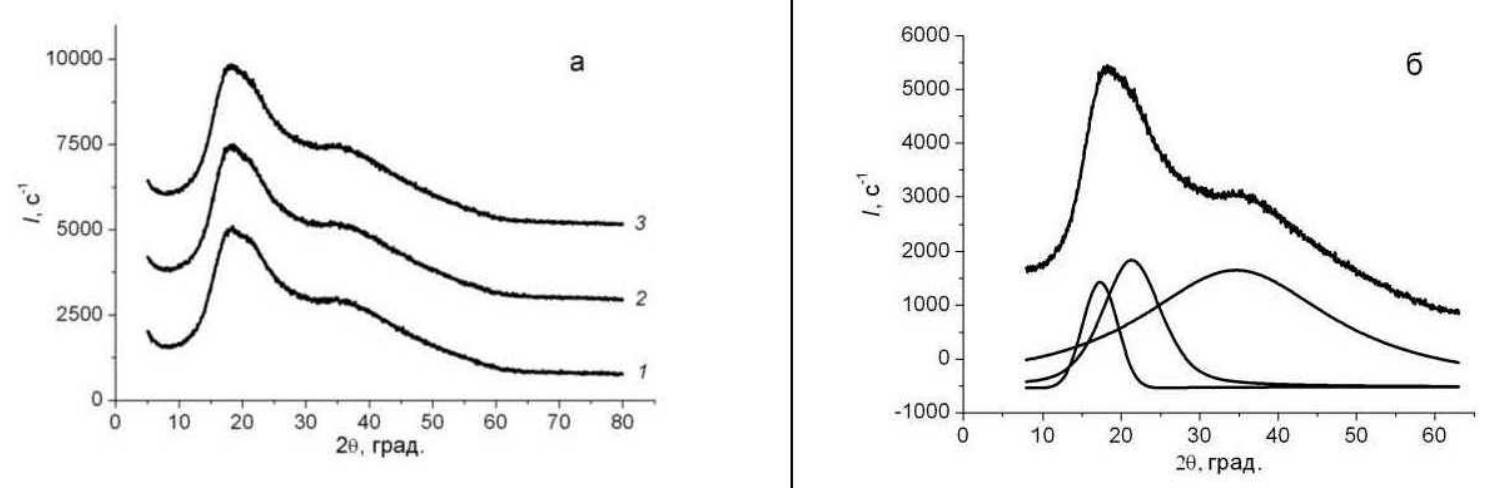

Рис. 7. Дифрактограми порошків з яблук (а), одержаних з паренхімних тканин, висушених при 60 (1), 80 (2) та $100{ }^{\circ}$ С (3). Розкладання дифрактограми (1) (б).
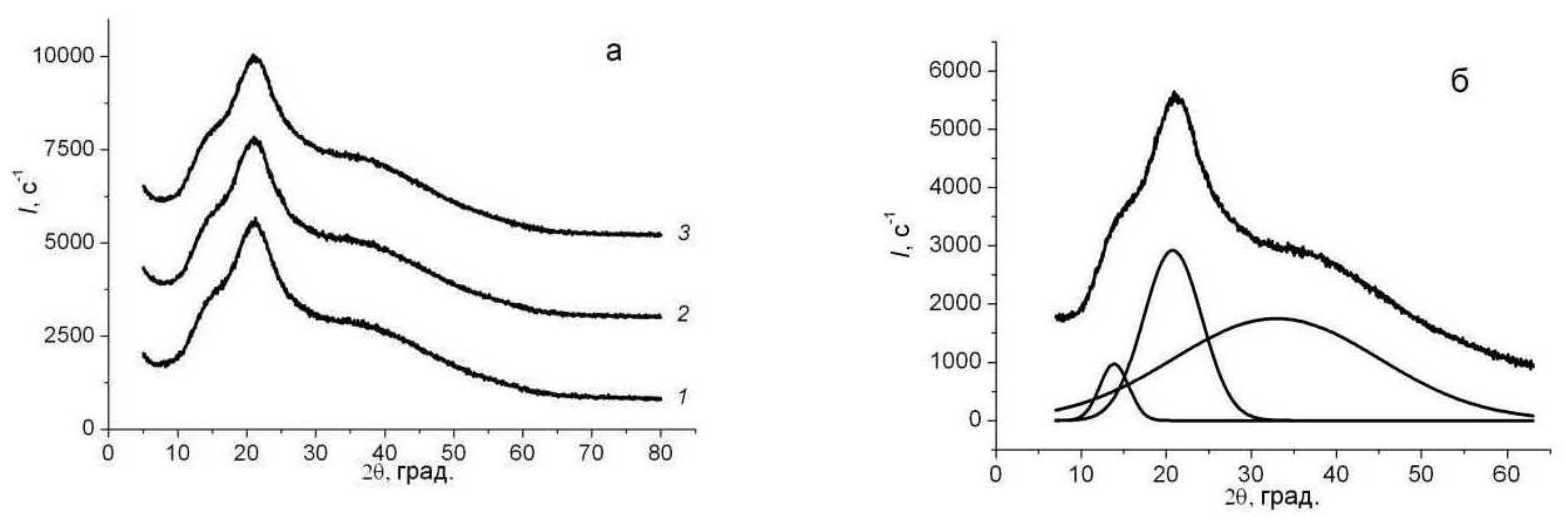

Рис. 8. Дифрактограми порошків з цукрового буряку, одержаних з тканин, висушених (а) при 60 (1), 80 (2) та $100^{\circ}$ С (3). Розкладання дифрактограми (1) (б).

3 яблук i $0,6 \ldots 0,4$ нм для порошків 3 буряку. Півширина перших двох піків знаходиться в межах 4...8 град. До менш кристалічних або аморфних відносяться ті області, в яких параметр періодичності складає 0,25...0,27 нм для обох продуктів, півширина третього піку досягає 28...29 град. Таким чином порошки можна віднести до частково кристалічних продуктів і визначити ступінь кристалічності $N_{x r d}$ за методом Метьюза [32], як відношення площі під кристалічними піками до загальної площі під дифракційними кривими в інтервалі кутів дифракції 10..60 град. В таблиці 2 отримані значення представлені параметром $I_{i n t}$ в \%. Тобто ступінь кристалічності порошку $N_{x r d}$ визначається як сума величин $I_{i n t}$ першої та другої дифракційних ліній. 3 огляду на розраховані величини $I_{i n t}$ ступінь кристалічності порошків з яблук становить 33,81 \%, а порошків 3 цукрового буряку -
36,28 \%. Відсутність видимої залежності ступеню кристалічності порошків від температури сушіння може бути пов' язане 3 малою чутливістю методу порошкової рентгенографії до внутрішньомолекулярних змін в високомолекулярних органічних сполуках.

Порівнюючи величини ступеня кристалічності (таблиці 2 та 3), одержані методами дериватографії $\left(N_{d t a}\right)$ та РФА $\left(N_{x r d}\right)$, бачимо, що вони близькі для порошку, отриманого 3 тканин цукрового буряку після сушіння при $60{ }^{\circ} \mathrm{C}$. Невелика різниця ( 2 \%) в значеннях $N_{d t a}$ та $N_{x r d}$ можлива за рахунок впливу теплоти термічної деструкції термолабільних компонентів на теплоту плавлення сахарози. Певний вклад в величину $N_{x r d}$ порошків (особливо яблучних) вносять і органічні кислоти, розчинність яких значно нижча [33], а швидкість кристалізації вища за таку для вуглеводів [34]. 
Таблиця 3. Характеристики дифракційних відбиттів порошків з яблука та цукрового буряку (сушіння при $\left.100^{\circ} \mathrm{C}\right)$ та ступінь кристалічності

\begin{tabular}{|c|c|c|c|c|c|c|c|}
\hline Порошок & № лінії & $\begin{array}{c}2 \theta, \\
\text { град. }\end{array}$ & $\begin{array}{l}d, \\
\text { нм }\end{array}$ & $\begin{array}{l}h_{1 / 2} \\
\text { град. }\end{array}$ & $\begin{array}{c}I_{\text {int }}, \\
\text { відносні } \\
\text { одиниці }\end{array}$ & $\begin{array}{c}I_{i n n}, \\
\%\end{array}$ & $\begin{array}{c}N_{x x d p} \\
\%\end{array}$ \\
\hline \multirow{3}{*}{ Яблучний } & 1 & 17.29 & 0.51 & 5.17 & 7181.41 & 10.08 & \multirow{3}{*}{33,81} \\
\hline & 2 & 21.33 & 0.42 & 8.81 & 16896.59 & 23.73 & \\
\hline & 3 & 34.61 & 0.26 & 29.74 & 47128.72 & 66.18 & \\
\hline \multirow{3}{*}{ Буряковий } & 1 & 13.9 & 0.64 & 4.01 & 2912.53 & 5.26 & \multirow{3}{*}{36,28} \\
\hline & 2 & 20.75 & 0.43 & 8.06 & 17160.70 & 31.02 & \\
\hline & 3 & 32.95 & 0.27 & 28.51 & 35244.39 & 63.71 & \\
\hline
\end{tabular}

РФА дає значно вищі значення $N_{x r d}$ для порошків 3 яблук. Цей факт $є$ ще одним доказом присутності в яблучних порошках крім глюкози кристалічних фаз сахарози та фруктози, визначити вміст яких методом дериватографії не вдалося. Розрахунок показує, що навіть якби глюкоза та сахароза повністю перейшли в кристалічний стан, то різниця між ступенем кристалічності яблучних порошків $N_{x r d}$ за даними РФА і сумою часток глюкози та сахарози в сухих речовинах яблук складе біля 6 \%. Отже, враховуючи визначену методом дериватографії ступінь кристалічності яблучних порошків $N_{d t a}$ та очікувану, орієнтуючись на величину ступеня кристалічності порошку з цукрового буряку, долю кристалічної сахарози, вміст кристалічної фруктози в сухих речовинах порошків буде значно вищим за $6 \%$.

\section{Висновки}

Дослідження впливу режиму конвективного сушіння на кристалічність порошків 3 яблук та цукрового буряку, проведені методами дериватографії та рентгенофазового аналізу, показали, що термічний метод аналізу виявився більш чутливим до змін вмісту кристалічної фази.

Методом диференціального термічного аналізу встановлено, що:

- температура сушіння через зміну швидкості сушіння та кристалізації впливає на ступінь кристалічності отриманого продукту;

- 3 підвищенням температури сушіння 3 60 до $100{ }^{\circ} \mathrm{C}$, при незмінній швидкості сушильного агента $1,5 \mathrm{M} / \mathrm{c}$, ступінь кристалічності порошку з буряку знижується з 34,0 до 20,4 \%, а порошку з яблук - 311,1 до 7,7 \%;

- ступінь кристалічності залежить від хімічного складу сировини і визначається, в основному, вмістом моно- та дисахаридів в ній;

Враховуючи негативний вплив температури сушіння на кристалічність продукту, пов'язаний зі зростанням швидкості сушіння, можна припустити, що збільшення швидкості сушильного агенту, призведе до аналогічного результату. Інтенсифікація процесів сушіння рослинної сировини 3 високим вмістом монота дисахаридів призводить до зниження ступеню кристалічності сухого продукту.

Рентгенофазовим аналізом ступінь кристалічності порошків 3 буряку визначена на рівні 36 \%, з яблук - 34 \%, проте залежності ступеню кристалічності порошків від зміни режиму сушіння виявити не вдалось.

Виходячи 3 рівня кристалічності, можна стверджувати, що досліджені порошки представляють собою аморфно-кристалічні продукти суміші біополімерів та розчинних вуглеводів в аморфному стані і кристалічних фаз, переважно глюкози, сахарози та фруктози в порошках 3 яблук, чи сахарози в порошках 3 цукрового буряку.

Кількість аморфної фази з ростом температури та швидкості сушіння зростає. Зростання вмісту цукрів в аморфному стані підвищує гігроскопічність порошків, особливо 3 високим вмістом фруктози, та збільшує вірогідність прояву фазових переходів другого роду.

Утворення кристалічних фаз вуглеводів 
протікає на завершальному етапі сушіння в розчинах 3 надто високим коефіцієнтом пересичення і супроводжується виділенням теплоти, інтегральна величина якої прямо залежить від маси кристалів та температури кристалізації [3].

Проведені дослідження показали, що фазові перетворення вуглеводів в сировині 3 високим вмістом моно- та дисахаридів необхідно враховувати в теоретичних розрахунках та теплових балансах процесу сушіння.

\section{ЛІТЕРАТУРА}

1. Михайлик В.А., Давыдова Е.О., Манк В.В. Исследование гидратации сахарозы методом низкотемпературной сканирующей калориметрии // Термодинамика органических соединений. Горький, 1989. - С. 76-80.

2. Михайлик B.A. Калориметрические исследования сахаров и сахаросодержащих материалов // Промышленная теплотехника. - 1998. T. 20, № 1. - C. 25-31.

3. Михайлик B.A. Применение термических методов исследования в решении научных и производственных задач энергоэффективности // Наукові праці Одеської національної академії харчових технологій, Міністерство освіти і науки України. - Одеса, 2007. - Вип. 31, Т.1. C. $170-177$

4. Михайлик В.А., Давыдова Е.О. Исследование состояния воды в сахаросодержащем растительном сырье при его обезвоживании // Промышленная теплотехника. - 2000. - Т. 22, № 5-6. - С. 50-54.

5. Михайлик В.А., Снежкин Ю.Ф. Влияние низких температур на состояние паренхимных тканей сахарной свеклы // Промышленная теплотехника. Приложение к журналу. - 2003. T. 25, № 4. - C. 169-171.

6. Гинзбург А.С. Сушка пищевых продуктов. Москва: Пищепромиздат, 1960. - 683 с.

7. Герасименко A.A. Кристаллизация сахара. Киев: Наукова думка, 1965. - 316 с.

8. Попов В.Д., Бажал И.Г. Кинетика уваривания сахарных утфелей // Известия высших учебных заведений. Пищевые технологии. - 1961. № 2. - C. 136-143.

9. Roos Y.H. Effect of moisture on the thermal behavior of strawberries studied using differential scanning calorimetry // Journal of Food Science. 1987. - Vol. 52(1). - P. 146-149.

10. Khalloufi S., El-Maslouhi Y., Ratti C. Mathematical model for prediction of glass transition temperature of fruit powders // Journal of Food Science. - 2000. - Vol. 65(5). - P. 842-848.

11. Wang H., Zhang S., Chen, G. Glass transition and state diagram for fresh and freeze-dried Chinese gooseberry // Journal of Food Engineering. - 2008. Vol. 84. - P. 307-312.

12. Moraga G., Marti'nez-Navarrete N., Chiralt $A$. Water sorption isotherms and phase transitions in kiwifruit // Journal of Food Engineering. - 2006. - Vol. 72. - P. 147-156.

13. Fabra M.J., Talens P., Moraga G., Martı'nezNavarrete $N$. Sorption isotherm and state diagram of grapefruit as a tool to improve product processing and stability // Journal of Food Engineering. - 2009. - Vol. 90. - P. 52-58.

14. Mrad N.D., Bonazzi C., Boudhrioua N., Kechaou N., Courtois F. Moisture Sorption Isotherms, Thermodynamic Properties, and Glass Transition of Pears and Apples // Drying Technology. - 2012. Vol. 30. - P. 1397-1406.

15. Mikhailik V.A., Dmitrenko N.V., Snezhkin Yu.F. Change in the Specific Heat Capacity of Parenchymal Tissues of Apples due to Dehydration // Journal of Engineering Physics and Thermophysics. - 2014. - Vol. 87, № 1. - P. 48-53.

16. Goula A.M., Karapantsios T.D., Achilias D.S., Adamopoulos K.G. Water sorption isotherms and glass transition temperature of spray dried tomato pulp // Journal of Food Engineering. - 2008. - Vol. 85(1). - P. 73-83.

17. Михайлик В.А., Хавін С.О., Реус І.А. Експериментальне дослідження кінетики сушіння ріпчастої цибулі // Енергетика, економіка, технології, екологія. - 2006. - № 2(19). C. $74-78$.

18. Михайлик В.А., Снєжкін Ю.Ф., Михайлик T.O. Дослідження кінетики сушіння $\mathrm{Na}+-$ заміщеної форми бентонітової глини (Черкаське родовище) // Керамика: наука и жизнь. -2009. № 3(5). - C. 4-11.

19. Паулик Ф., Паулик Й., Эрдеи Л. Дериватограф. Теоретические основы // Венгерский оптический завод. - Будапешт, 1974. - 146 с.

20. Рабинович В.А., Хавин 3.Я. Краткий хими- 
ческий справочник; ред. В. А. Рабинович. - 2-е изд., испр. и доп. - Л.: Химия. Ленинградское отделениение, 1978. - 392 с.

21. Михайлик В.А., Снєжкин Ю.Ф., Белинский B.T. Применение дериватогафа для исследования влияния предварительной термической обработки на кинетику сушки растительного сырья // Проблемы промышленной теплотехники: IV Междунар. конф., 26-30 сент. 2005г. : тезисы докл. - К., 2005. - С. 349-350.

22. Зевин Л.С., Завьялова Л.Л. Количественный рентгенографический фазовый анализ. - М.: Недра, 1974. - 183 с.

23. Количество углеводов в яблоках [Электронный ресурс] // Notefood 2015. Журнал о правильном питании. Пищевые вещества [сайт] - Режим доступа: http://notefood.ru/pishhevyeveshhestva/uglevody/kolichestvo-uglevodov-vyabloke.html

24. Силин П.М. Технология сахара - 2-е изд., перераб. и доп. - М.: Пищевая промышленность, 1967. $-624 \mathrm{c}$.

25. Основные факторы, влияющие на процесс экстрагирования сахарозы из свеклы [Электронный ресурс] // Информационный портал Пищевик [сайт] - Режим доступа: http://mppnik. ru/publ/1203-osnovnye-faktory-vliyayuschie-naprocess-ekstragirovaniya-saharozy-iz-svekly.html

26. Принциипь технологии сахара : Пер. с англ. / Под ред. П. Хонига. - М.: Пищепромиздат, $1961,-616$ c.

27. Hurtta M., Pitkanen I., Knuutinen J. Melting behaviour of D-sucrose, D-glucose and D-fructose // Carbohydrate Research. - 2004. - № 339. P. 2267-2273.

28. Шестак Я. Теория термического анализа: Физико-химические свойства твердых неорганических веществ : Пер. с англ. - М.: Мир, 1987. $-456 \mathrm{c}$.

29. Уэндланд У. Термические методы анализа: Пер. с англ. / Под ред. В.А. Степанова и В.А. Берштейна. - М.: Мир, 1978. - 526 с.

30. Переоохолоджена рідина [Електронний ресурс] // Вікіпедія. Вільна енциклопедія [сайт] - Режим доступу: http://uk.wikipedia.org/wiki/ Переохолоджена_рідина

31. Ивчук Н.П., Бобровник Л.Д., Танашук Л.И., Назарова О.П., Скрипник В.Ф. Растворимость глюкозы и фруктозы в системе вода - фруктоза - глюкоза // Сахарная промышленность. - 1994. - №2. - С. 30 .

32. Липатов Ю.С., Шилов В.В., Гомза Ю.П., Кругляк Н.Е. Рентгенографические методы изучения полимеров. - Киев: Наукова думка, 1982. $-296 \mathrm{c}$.

33. Гороновский И.Т., Назаренко Ю.П., Некряч У.Ф. Краткий справочник по химии. - 4-е изд., испр. и доп. - Киев: Наукова думка, 1974. $-991 \mathrm{c.}$

34. Кристаллизаџия и свойства кристаллических веществ : сборник научных трудов // Академия наук СССР, Кольский филиал им. С.М. Кирова ; отв. ред. С. М. Бондин. Л: Наука. Ленинградское отделение, 1971. - 97 с. 


\section{IMPACT OF THE MODE OF CONVECTIVE DRYING ON THE CRYSTALLINITY OF APPLE AND SUGAR BEET POWDERS}

\section{Mykhailyk V.A. ${ }^{1}$, Snezhkin Yu.F. ${ }^{1}$, Korinchevska T.V. ${ }^{1}$, Gornikov Yu.I. ${ }^{2}$}

1 Institute of Engineering Thermophysics of National Academy of Sciences of Ukraine, 2a Zhelyabova Str., Kyiv, 03680, Ukraine

2 Chuiko Institute of Surface Chemistry of National Academy of Sciences of Ukraine, 17 General Naumov Str., Kyiv, 03164, Ukraine

The effect of temperature of the convecting drying on the crystallinity of apple and sugar beet powders was presented in this study. The X-ray diffraction and derivatography methods were used. The data of thermal analysis revealed that with increasing of drying temperature from 60 to $100{ }^{\circ} \mathrm{C}$ at a constant speed of drying agent $(1.5 \mathrm{~m} / \mathrm{s})$, the degree of crystallinity was reduced from $34.0 \%$ wt. to $20.4 \% \mathrm{wt}$. and from $11.1 \%$ wt. to $7.7 \% \mathrm{wt}$. for the sugar beet and apple powders, respectively. The X-ray diffraction method showed that the crystallinity of sugar beet and apple powders were $36 \%$ wt. and $34 \% \mathrm{wt}$., respectively. The formation of crystalline phases of carbohydrates occurs only at the final stage of drying in the solutions with a very high coefficient of supersaturation. The investigated powders are semicrystalline product according to their degree of crystallinity. E.g., the apple powder is a mixture of amorphous (biopolymers and soluble carbohydrates) and crystalline (glucose, sucrose and fructose) phases. References 34, tables 3, figures 8.

Key words: drying, sugar beet, apple, crystallization, sucrose, glucose, fructose, derivatography, X-ray diffraction, phase transitions, the degree of crystallinity.

1. Mykhailyk V.A., Davydova E.O., Mank V.V. Study of hydration of sucrose by lowtemperature scanning calorimetry // Termodinamika organicheskih soedineniy. - Gorky, 1989. - P. 76-80. (Rus.)

2. Mykhailyk V.A. Calorimetric studies of sugars and sugar-containing materials // Promyshlennaya teplotekhnika - 1998. - Vol. 20, № 1. - P. 25-31. (Rus.)

3. Mykhailyk V.A. The application of thermal methods of research in solving scientific and industrial problems of energy efficiency // Naukovi pratsi Odes'koyi national'noyi akademiyi kharchovykh tekhnolohiy, Ministerstvo osvity i nauky Ukrayiny. Odessa, 2007. - Issue 31, Vol. 1. - P. 170-177. (Rus.)

4. Mykhailyk V.A., Davydova E.O. Study of the state of water in the sugar-containing vegetable raw materials during its dehydration // Promyshlennaya teplotekhnika - 2000. - Vol. 22, № 5-6. - P. 50-54. (Rus.)

5. Mykhailyk V.A., Snezhkin Yu.F. Influence oflow temperature on the condition of parenchymal tissues of sugar beet // Promyshlennaya teplotekhnika. Prilozheniye k zhurnalu. - 2003. - Vol. 25, № 4. P. 169-171. (Rus.)

6. Ginzburg, A.S. Drying of the foodstuffs. Moscow: Pishchepromizdat, 1960.-683 p. (Rus.)

7. Gerasimenko A.A. Crystallization of the sugar. - Kiev: Naukova dumka, 1965. - 316 p. (Rus.)

8. Popov V.D. Bazhal I.G. Kinetics of boiling of sugar massecuite // Izvestiya vysshikh uchebnykh zavedeniy. Pishchevyye tekhnologii. - 1961. - № 2. - P. 136-143. (Rus.)

9. Roos Y.H. Effect of moisture on the thermal behavior of strawberries studied using differential scanning calorimetry // Journal of Food Science. 1987. - Vol. 52(1). - P. 146-149.

10. Khalloufi S., El-Maslouhi Y., Ratti C. Mathematical model for prediction of glass transition temperature of fruit powders // Journal of Food Science. - 2000. - Vol. 65(5). - P. 842-848.

11. Wang H., Zhang S., Chen, G. Glass transition and state diagram for fresh and freeze-dried Chinese gooseberry // Journal of Food Engineering. - 2008. Vol. 84. - P. 307-312.

12. Moraga G., Marti'nez-Navarrete N., Chiralt $A$. Water sorption isotherms and phase transitions in kiwifruit// Journal of Food Engineering. - 2006. - Vol. 72. - P. 147-156.

13. Fabra M.J., Talens P., Moraga G., Martı'nezNavarrete $N$. Sorption isotherm and state diagram of grapefruit as a tool to improve product processing and stability // Journal of Food Engineering. - 2009. - Vol. 90. - P. 52-58. 
14. Mrad N.D., Bonazzi C., Boudhrioua N., Kechaou N., Courtois F. Moisture Sorption Isotherms, Thermodynamic Properties, and Glass Transition of Pears and Apples // Drying Technology. - 2012. Vol. 30. - P. 1397-1406.

15. Mikhailik V.A., Dmitrenko N.V., Snezhkin Yu.F. Change in the Specific Heat Capacity of Parenchymal Tissues of Apples due to Dehydration // Journal of Engineering Physics and Thermophysics. - 2014. - Vol. 87, № 1. - P. 48-53.

16. Goula A.M., Karapantsios T.D., Achilias D.S., Adamopoulos K.G. Water sorption isotherms and glass transition temperature of spray dried tomato pulp // Journal of Food Engineering. - 2008. - Vol. 85(1). - P. 73-83.

17. Mykhailyk V.A., Havin S.O., Reus I.A. Experimental study of the drying kinetics of bulb onion // Enerhetyka, ekonomika, tekhnolohiyi, ekolohiya. - 2006. - №2 (19). - P. 74-78. (Ukr.)

18. Mykhailyk V.A., Snezhkin Yu.F.,Mykhailyk T.O. Study of drying kinetics of $\mathrm{Na}+$-substituted form of bentonite clay (Cherkasy fieldt) // Keramika nauka i zhizn'. - 2009. - №3 (5). - P. 4-11. (Ukr.)

19. Paulik F., Paulik J., Erdei L. Derivatograph of the system. Theoretical foundations // Vengerskyi optisheskyi zavod. - Budapesht, 1974. - 146 p. (Rus.)

20. Rabinovich V.A., Havin Z. Ya. Abrief chemical handbook; edited by V.A. Rabinovich. - 2nd edition, corr. and add. - L.: Khimia, Leningradskoe otdelenie, 1978. - 392 p. (Rus.)

21. Mykhailyk V.A., Snezhkin Yu.F., Belinsky V.T. Application of derivatograph for research of influence of preliminary heat treatment on the kinetics of drying vegetable raw materials // Problemy promyshlennoy teplotekhniki : IV Intern. conf., Sept. 26-30. 2005. : abstracts. - K., 2005 - P. 349 - 350. (Rus.)

22. Zevin L.S., Zavyalova L.L. Quantitative radiographic phase analysis. - M.: Nedra, 1974. 183 p. (Rus.)

23. The quantity of carbohydrates in apples [A electronic resource] // Notefood 2015. Zhurnal o pravil'nom pitanii. Pishchevyye veshchestva [website] - Access: http://notefood.ru/pishhevyeveshhestva/uglevody/kolichestvo-uglevodov-vyabloke.html (Rus.)
24. Silin P.M. Technology of sugar -2 nd edition, revised and added. - M.: Pishchevaya promyshlennost', 1967. - 624 p. (Rus.)

25. The main factors influencing the process of extracting sucrose from beet [A electronic resource]

// Informatsionnyy portal Pishchevik [website] - Access: http://mppnik.ru/publ/1203-osnovnyefaktory-vliyayuschie-na-process-ekstragirovaniyasaharozy-iz-svekly.html (Rus.)

26. Principles of technology of sugar : Trans. from English / Ed. P. Honig. - M.: Pishchepromizdat, $1961-616$ p. (Rus.)

27. Hurtta M., Pitkanen I., Knuutinen J. Melting behaviour of D-sucrose, D-glucose and D-fructose // Carbohydrate Research. - 2004. - № 339. - P. 2267 2273.

28. Shestak Ya. Theory of thermal analysis: physical and chemical properties of inorganic solids : Trans. from English. - M.: Mir, 1987. - 456 p.

29. Wendland $W$. Thermal Methods of Analysis : Trans. from English / Ed. V.A. Stepanov and V.A. Berstein - M.: Mir, 1978. - 526 p. (Rus.)

30. Supercooled fluid [Electronic resource] // Wikipedia. The Free Encyclopedia [website] - Access: http://uk.wikipedia.org/wiki/ Переохолоджена_рідина (Ukr.)

31. Ivchuk N.P., Bobrovnik L.D., Tanaschuk L.I., Nazarova O.P., Skripnik V.F. The solubility of glucose and fructose in the water-fructose-glucose system // Sakharnaya promyshlennost'. - 1994. № 2. - P. 30. (Rus.)

32. Lipatov Yu.S., Shilov V.V., Gomza YU.P., Kruglyak N.E. Radiographic methods of studying polymers. - Kiev: Naukova dumka, 1982. - 296 p. (Rus.)

33. Goronovsky I.T., Nazarenko Yu.P., Nekryach U.F. A brief handbook on chemistry. - 4th edition, corr. and add. - Kiev: Naukova dumka, 1974. 991 p. (Rus.)

34. The crystallization and properties of crystalline substances : collection of scientific papers // Academy of Sciences of the USSR, the Kola branch of them. SM Kirov; Ans. Ed. S.M. Bondin. - L.: Nauka, Leningradskoe otdelenie, 1971. - 97 p. (Rus.) 